\title{
Strength Properties of Hydraulic Cement Concrete Pavement Incorporating Coconut Shell as Coarse Aggregate
}

\section{Ogbonna Alban Chidiebere*, Abubakar Mikailu}

Department of Civil Engineering, Waziri Umaru Federal Polytechnic, Birnin Kebbi, P.M.B 1034 Birnin Kebbi G.P.O, Birnin Kebbi City, Kebbi State, Nigeria

Corresponding author: alban.ogbonna@yahoo.com

$\Gamma$ crossef http://dx.doi.org/10.5755/j01.sace.18.1.16664

Coconut shell being a hard and not easily degradable material if crushed to size of coarse aggregate can be a potential material to replace coarse aggregate in concrete. In this study the characteristics of the coarse aggregate and the coconut shell were evaluated. Properties of fresh and hardened concrete with partial replacement of coarse aggregate with coconut shell were also studied. Concrete specimens with $0 \%, 5 \%, 10 \%, 15 \%$ and $20 \%$ by weight of coarse aggregate replacement with coconut shell were made at 1:2:4 mix ratio. The compressive strength for all the concrete specimens was evaluated at 7, 14, 21 and 28 days and constant water cement ratio of 0.5 was maintained for all the concrete specimens. The aggregate crushing value of the coarse aggregate and the coconut shell were $23.47 \%$ and $28.25 \%$ respectively and the aggregate impact value of the coarse aggregate and the coconut shell were $17.44 \%$ and $20.2 \%$ respectively. The slump values, densities and compressive strength of concrete decreased as the percentage replacement with coconut shell increased. Concrete produced with $0 \%, 5 \%, 10 \%$, $15 \%$ and $20 \%$ replacement attained 28 days compressive strength of $38.17,35.11,32.14,31.18$, and $29.14 \mathrm{~N} / \mathrm{mm}^{2}$ respectively. The results obtained in this study showed that coconut shell satisfied the requirements for coarse aggregate and can be used as partial replacement of coarse aggregate (up to $20 \%)$ in concrete pavement production.

KEYWORDS: Coarse aggregate, Coconut shell, Concrete pavement, cement, Strength properties.

There are many research works conducted to improve the engineering properties of concrete by partial or full replacement of coarse aggregate, fine aggregate or cement paste ( $\mathrm{ACl}$ 318/318R -08, 2009, Gunasekaran et al, 2011, and Olanipekun, 2006). Cement mortar and concrete are the most widely used construction material. It is difficult to point out another material of construction which is versatile as concrete. It is the material of choice where strength, permanence, durability, impermeability, fire resistance and abrasion resistance are required. It is also closely associated with every human activity that it touches every human being in his day to day living (Shetty, 2013). Infrastructure development across the world created demand for construction materials. Concrete manufacturing involve consumption of ingredients like cement, aggregates, water and admixtures (Amarnath, and Ramachandrudu, 2012, Parag, and Sandhya, 2014, and Shetty, 2013). Among all

\section{Introduction}

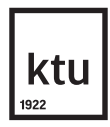

Journal of Sustainable Architecture and Civil Engineering Vol. 1 / No. 18 / 2017 pp. $73-80$

DOI 10.5755/j01.sace.18.1.16664 (c) Kaunas University of Technology

Strength Properties of Hydraulic Cement Concrete Pavement Incorporating Coconut Shell as Coarse Aggregate

Received 2016/11/29

Accepted after revision 2017/01/18 
the ingredients, aggregates form the major part (Amarnath, and Ramachandrudu, 2012). It is incredibly versatile and is used in almost all major construction projects (Amarnath, and Ramachandrudu, 2012, Parag, and Sandhya, 2014, and Shetty, 2013). Aggregates typically consist of $60 \%-70 \%$ of the volume of a concrete mixture (Shetty, 2013). Use of natural aggregates in such a rate leads to question about the preservation of natural aggregates sources (Amarnath, and Ramachandrudu, 2012). In addition, operations associated with aggregate extraction and processing are the principal course of environmental concerns (Osei, 2013, and Shetty, 2013). The negative consequences of increasing demand of aggregates include depletion of aggregate deposits, environmental degradation and ecological imbalance (Osei 2013). The possibility of a complete depletion of aggregate resources has rendered continued use of aggregates in construction works unsustainable (Naik, 2008).

Research addressing environmental and sustainability issues in construction has generated lots of interest in the world (Akshay, et al 2014, Gunasekaran, et al 2011, and Olanipekun, et al 2006). The use of waste materials saves natural resources and dumping spaces, and helps to maintain a clean environment, (Parag, and Sandhya, 2014).

Coconut shell being a hard and not easily degradable material if crushed to size of coarse aggregate can be a potential material to substitute coarse aggregate in concrete (Akshay et al, 2014, Gunasekaran, et al 2011, and Olanipekun, et al 2006). According to Olanipekun, et al (2006) and Gunasekaran, et al (2011), limited research has been conducted on mechanical properties of concrete with coconut shell as aggregate replacement. Coconut shells are agricultural waste produced as by products of coconut oil production (Osei, 2013). The potential of using agricultural wastes in civil engineering works have been investigated by various researchers. In a study, Olanipekun et al, (2006) compared concrete made with coconut shells and palm kernel shells as replacement for natural coarse aggregates and concluded that coconut shells performed better than palm kernel shells as replacement for conventional aggregates in concrete pavement. In an experimental assessment on coconut shell as aggregate in concrete, Osei, (2013) concluded that $18.5 \%$ replacement by volume of crushed granite with coconut shell can be used to produce structural concrete in line with BS 8110.

The coconut shell aggregate has higher water absorption because of higher porosity in its shell structure (Gunasekaran et al, 2011, Kakade, and Dhawale, 2015, and Olanipekun et al, 2006). The aggregate impact value of coconut shell aggregate is much lower compared to crushed aggregate which indicates that this aggregate have good absorbance to shock (Kakade, and Dhawale, 2015). In a study Parag, and Sandhya, (2014) concluded that the coconut shell has potential as light weight aggregate in concrete and using the coconut shell as aggregate in concrete can reduce the material cost in construction because of the low cost of abundant agricultural waste. They suggested that Coconut shell concrete can be used in rural areas and places where coconut is abundant and may also be used where the conventional crushed aggregates are costly. In a study Akshay et al, (2014) concluded that coconut shell aggregate concrete satisfied the requirements of ASTM C330/C330M-14 (2014). They have it that to increase the speed of construction, enhance green construction environment, we can use lightweight concrete. The possibility exists for the partial replacement of coarse aggregate with coconut shell to produce light weight concrete.

This research work is aimed at assessing the strength properties of hydraulic cement concrete pavement incorporating coconut shell as coarse aggregate. The major objectives of this work are: to examine the properties of concrete pavement produced by partial replacement of coarse aggregate (crushed granites) with coconut shell at different percentages and to enlighten the relevant agencies, professional bodies, consultancy and construction firms on the potential use of coconut shell in concrete production. 


\section{Cement}

The hydraulic cement used in this study conform with the specifications of ASTM C150/ C150-16 e1 (2016) ASTM C1157/C1157M-11 and AASHTO M85 (2016).

\section{Materials and methods}

\section{Aggregates}

Aggregates were selected in accordance with AASHTO (2013, 2015), ASTM 127-15 (2015), ASTM D448 (2012), ASTM C33/C33M (2013), ASTM C29/C29M (2016), ASTM C330/C330M-14 (2014), WSDOT M46-01.15 (2013), WSDOT M46-01.24 (2016), and WSD0T M41-10 (2013). Crushed granites passing through sieve $25 \mathrm{~mm}$ but retained in sieves $19 \mathrm{~mm}, 12.5 \mathrm{~mm}, 10 \mathrm{~mm}$ and $4.75 \mathrm{~mm}$ was used as coarse aggregate. Coconut shell was obtained locally and crushed into smaller sizes passing through sieve $25 \mathrm{~mm}$ but retained on sieve $19 \mathrm{~mm}, 12.5 \mathrm{~mm}, 10 \mathrm{~mm}$ and $4.75 \mathrm{~mm}$. The coconut shell aggregate were air dried for 21 days. Fibre and husk on dried shells were carefully removed.

\section{Mix Design}

Table 1 shows the design mix used for this study. The concrete specimens were prepared at the mix ratio of 1:2:4 by weight and marked as shown in Table 1. The control mix (G1) with 0\% coconut shell was prepared. Subsequently samples G2, G3, G4 and G5 were prepared with 5\%, 10\%, 15\% and $20 \%$ replacement by weight of coarse aggregates with coconut shell.

\begin{tabular}{|c|c|c|c|c|c|c|}
\hline \multirow{2}{*}{$\begin{array}{l}\text { Concrete } \\
\text { specimen } \\
\text { mark }\end{array}$} & \multirow{2}{*}{$\begin{array}{c}\text { Percentage } \\
\text { replacement with } \\
\text { coconut shell (\%) }\end{array}$} & \multirow{2}{*}{$\begin{array}{l}\text { Cement } \\
\text { content } \\
\left(\mathrm{kg} / \mathrm{m}^{3}\right)\end{array}$} & \multirow{2}{*}{$\begin{array}{l}\text { fine aggregate } \\
\text { content } \\
\left(\mathrm{kg} / \mathrm{m}^{3}\right)\end{array}$} & \multicolumn{2}{|c|}{ Coarse aggregate content } & \multirow{2}{*}{$\begin{array}{l}\text { Water } \\
\text { cement } \\
\text { ratio (\%) }\end{array}$} \\
\hline & & & & $\begin{array}{c}\text { Crushed } \\
\text { granite }\left(\mathrm{kg} / \mathrm{m}^{3}\right)\end{array}$ & $\begin{array}{c}\text { Coconut } \\
\text { shell }\left(\mathrm{kg} / \mathrm{m}^{3}\right)\end{array}$ & \\
\hline G1 & 0 & 357 & 714 & 1428 & 0 & 0.5 \\
\hline $\mathrm{G} 2$ & 5 & 357 & 714 & 1356.6 & 71.4 & 0.5 \\
\hline G3 & 10 & 357 & 714 & 1285.2 & 142.8 & 0.5 \\
\hline G4 & 15 & 357 & 714 & 1213.8 & 214.2 & 0.5 \\
\hline G5 & 20 & 357 & 714 & 1142.4 & 285.6 & 0.5 \\
\hline
\end{tabular}

\section{Sieve Analysis}

Combined sieve analysis was conducted for fine aggregate, coarse aggregate and coconut shell in accordance with AASHTO (2013, 2015), ASTM C136/C136M-14 (2014), ASTM D6913-04 (2009), ASTM D448 (2012), WSDOT M46-01.15 (2013), WSDOT M46-01.24 (2016), and WSDOT M41-10 (2013). The sieve analysis involves the passing of original samples through a stack of sieves arranged in descending order of the openings of the sieves, with larger sieves on the top. The materials retained on each sieve after shaking, represents the fraction of the aggregates coarser than the sieve in question and finer than the sieve above.

\section{Aggregate Impact Value (AIV) Test}

The aggregate impact value test gives relative measure of the resistance of an aggregate to sudden shock or impact (Udoeyo, and Dashibil, 2002). The aggregate impact value (AIV) was conducted for the coarse aggregate and the coconut shell in accordance with AASHTO $(2013,2015)$, ASTM D5874-02 (2007), ASTM C131/C131M-14 (2006), WSDOT M46-01.15 (2013), and WSDOT M46-01.24 (2016).

\section{Aggregate Crushing Value (ACV) Test}

The aggregate crushing value gives a relative measure of the resistance of an aggregate to crushing under a gradually applied compressive load (Shetty 2013). The aggregate crushing value test 
was conducted for both coarse aggregate and coconut shell in accordance with ASTM D5874- 02 (2007), ASTM C131/C131M -14 (2006), ASTM C192/ 192M -15 (2015), and WSDOT M46-01.24 (2016).

\section{Slump Test}

According to AASHTO (2013), AASHTO (2015), BSEN 12350-02 (2009), BSEN 206-1(2006)], the slump test is a measure of the consistency of the concrete and a change in the slump test indicates that something in the manufacturing of the concrete has changed. Slump test was conducted on the fresh concrete in accordance with [AASHTO $(2013,2015)$, ASTM C143/C143M - 15 (2015), ASTM C1611 (2015), WSDOT M46-01.15 (2013), and WSDOT M46-01.24 (2016)].

\section{Compressive Strength Test}

Compressive strength test was performed on the hardened concrete in accordance with AASHTO (2013, 2015), ACI 318/318R, ASTM C495/C495M (2012), WSDOT M46-01.15 (2013), WSDOT M4601.24 (2016), and WSDOT M41-10 (2013). The test specimens were of the size $150 \mathrm{~mm} \times 150 \mathrm{~mm}$ $x 150 \mathrm{~mm}$. The filling of the moulds was in three layers of $50 \mathrm{~mm}$ each. The concrete cubes were compacted manually using $16 \mathrm{~mm}$ diameter rod at 40 evenly distributed strokes per layer. The samples were marked and cured in clean fresh tap water and were maintained at a room temperature. Three specimens from each of the five different mixes were crushed at 7, 14, 21 and 28 days age respectively and the average compressive strength were recorded.

\section{Results and discussion}

Table 2

Combined aggregate gradation (fine aggregate, coarse aggregate and coconut shell)

\section{Table 3}

Physical and mechanical properties of fine aggregate, coarse aggregate and coconut shell

\begin{tabular}{c|c|c|c}
\hline $\begin{array}{c}\text { Sieve size } \\
(\mathrm{mm})\end{array}$ & $\begin{array}{c}\text { Percentage } \\
\text { retained (\%) }\end{array}$ & $\begin{array}{c}\text { Cumulative percentage } \\
\text { Retained (\%) }\end{array}$ & $\begin{array}{c}\text { Percentage pass- } \\
\text { ing /finer (\%) }\end{array}$ \\
\hline 25 & 0.00 & 0.00 & 100.00 \\
\hline 19 & 4.18 & 4.18 & 95.82 \\
\hline 12.5 & 17.84 & 22.02 & 77.98 \\
\hline 9.5 & 15.11 & 37.13 & 62.87 \\
\hline 4.75 & 12.81 & 49.94 & 50.06 \\
\hline 2.36 & 8.88 & 58.82 & 41.18 \\
\hline 1.18 & 9.78 & 68.60 & 31.40 \\
\hline 0.6 & 1.16 & 80.76 & 19.24 \\
\hline 0.3 & 7.48 & 88.24 & 11.76 \\
\hline 0.15 & 5.20 & 93.44 & 6.56 \\
\hline 0.075 & 4.26 & 97.70 & 2.30 \\
\hline
\end{tabular}

\begin{tabular}{l|c|c|c}
\multicolumn{1}{c|}{ Properties } & $\begin{array}{c}\text { Fine } \\
\text { aggregate }\end{array}$ & $\begin{array}{c}\text { Coarse } \\
\text { aggregate }\end{array}$ & Coconut shell \\
\hline Specific gravity & 2.6 & 2.70 & 1.63 \\
\hline Water absorption (\%) & 1.11 & 2.1 & 4.48 \\
\hline Aggregate crushing value (\%) & - & 23.47 & 28.25 \\
\hline Aggregate impact value (\%) & - & 17.44 & 20.20 \\
\hline
\end{tabular}

\section{Aggregates characteristics}

The results of the combined gradation of coarse aggregate, coconut shell, and fine aggregate are shown in $\mathrm{Ta}$ ble 2. The results of the physical and mechanical properties of the coarse aggregate, fine aggregate and coconut shell are shown in Table 3. These properties conform to the requirements of coarse aggregate for concrete pavement in accordance with ASTM D5874 - 02 (2007), ASTM C131/ C131M -14 (2006), ASTM 127 -15 (2015), ASTM D448 (2012), ASTM C33/C33M (2013), ASTM C330/ C330M-14 (2014). 


\section{Properties of concrete incorporating coconut shell}

Table 4, shows the slump, density and compressive strength values of concrete at different percentage replacement of coarse aggregate with coconut shell. The slump decreased with increase in coconut shell percentage. The control mix with $0 \%$ coconut shell showed higher compressive strength. Furthermore, the compressive strength decreased with coconut shell percentage increase. Fig. 1 shows the relationship between 28 day and 56 day compressive strength with percentage replacement of coarse aggregate with coconut shell. Fig. 2 shows the relationship

\begin{tabular}{|c|c|c|c|c|c|c|c|c|}
\hline \multirow{2}{*}{$\begin{array}{c}\text { Specimen } \\
\text { mark }\end{array}$} & \multirow{2}{*}{$\begin{array}{c}\text { Percentage } \\
\text { replacement of } \\
\text { coarse aggregate } \\
\text { with coconut shell (\%) }\end{array}$} & \multirow{2}{*}{$\begin{array}{l}\text { Slump } \\
(\mathrm{mm})\end{array}$} & \multirow{2}{*}{$\begin{array}{l}\text { Density } \\
\left(\mathrm{kg} / \mathrm{m}^{3}\right)\end{array}$} & \multicolumn{5}{|c|}{ Average compressive strength $\left(\mathrm{N} / \mathrm{mm}^{2}\right)$} \\
\hline & & & & 7 day & 14 day & 21 day & 28 day & 56 day \\
\hline M1 & 0 & 83 & 2490 & 26.84 & 31.87 & 35.11 & 38.17 & 42.22 \\
\hline M2 & 5 & 77 & 2467 & 23.67 & 28.01 & 33.08 & 35.11 & 41.54 \\
\hline M3 & 10 & 63 & 2348 & 21.01 & 25.04 & 29.78 & 32.14 & 38.65 \\
\hline M4 & 15 & 60 & 2380 & 19.18 & 23.66 & 25.11 & 31.18 & 35.23 \\
\hline M5 & 20 & 57 & 2336 & 17.11 & 21.17 & 23.18 & 29.14 & 33.06 \\
\hline
\end{tabular}

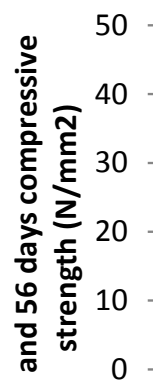

జ

0

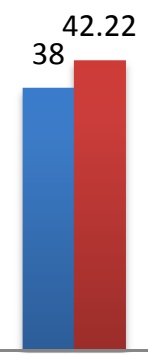

0

5

41.54

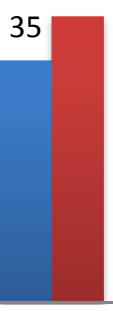

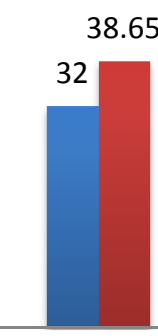

10

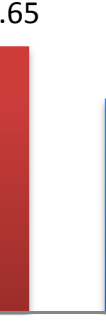

Percentage replacement of coarse aggregate with coconut shell (\%)

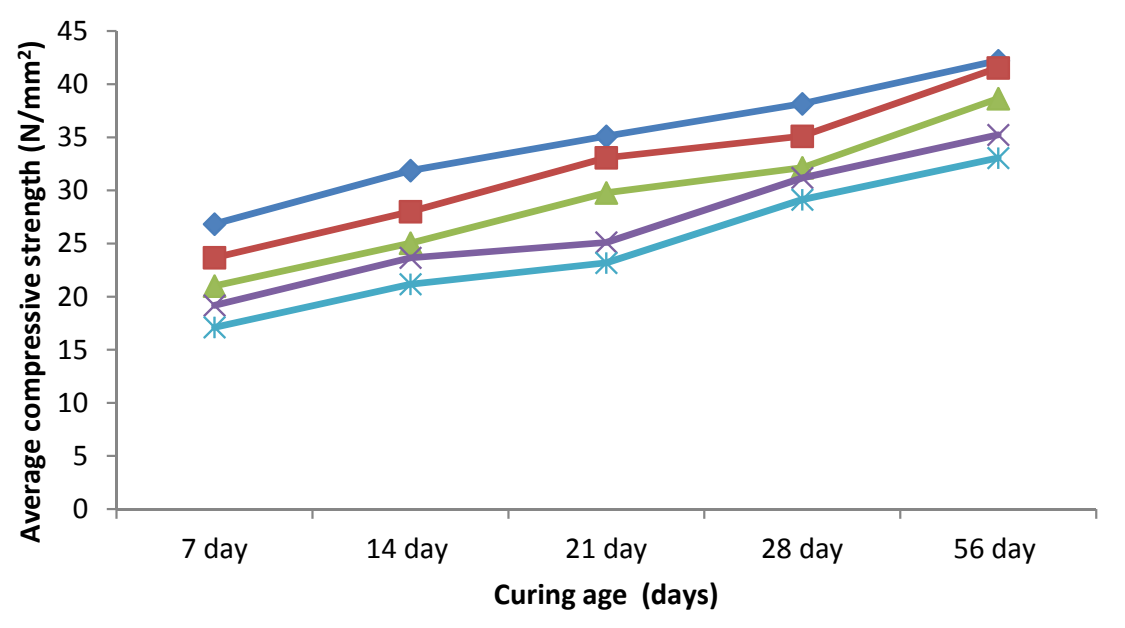

\section{Table 4}

Properties of concrete incorporating coconut shell as partial replacement of coarse aggregate

\section{Fig. 1}

Relationship between 28 day and 56 day compressive strength and percentage replacement with coconut shell
Fig. 2

Relationship between the average compressive strength with curing age 
between compressive strength and age of the concrete specimens. There were good relationships between these variables. The results conformed to the specifications of AASHTO $(2013,2015), A C l$ 318/318R, ASTM C495/C495M (2012), WSD0T M46-01.15 (2013), WSD0T M46-01.24 (2016), and WSDOT M41-10 (2013).

Conclusion and recommendations
Based on the results and discussions presented in this research, the following conclusions were drawn;

1 The use of coconut shell in concrete pavement production will contribute to resource conservation of natural aggregate, environmental protection and reduction in the cost of construction since this agricultural waste can be obtained at little or no cost.

Coconut shell characteristics satisfied the requirement for concrete coarse aggregate and can be used as partial replacement of coarse aggregate in concrete production in accordance with ASTM D5874-02 (2007), ASTM C131/C131M -14 (2006), ASTM 127-15 (2015), ASTM D448 (2012), ASTM C33/C33M (2013), ASTM C330/C330M -14 (2014), WSDOT M46-01.15 (2013), WSDOT M46-01.24 (2016), and WSDOT M41-10 (2013).

3 The properties of concrete incorporating up to $20 \%$ coconut shell aggregate satisfied the minimum requirement of $28 \mathrm{~N} / \mathrm{mm}^{2}$ for 28 days compressive strength for standard concrete pavement as specified by ASTM D5874-02 (2007), ASTM C131/C131M -14 (2006), ASTM 127-15 (2015), ASTM D448 (2012), ASTM C33/C33M (2013), ASTM C330/C330M -14 (2014), WSDOT M46-01.15 (2013), WSDOT M46-01.24 (2016), and WSDOT M41-10 (2013).

Percentage increase in coconut shell replacement reduces the compressive strength, density and slump values of concrete.

5 Developing counties should encourage the use concrete pavement and structural concrete incorporating coconut shell up to $15 \%$ by weight of coarse aggregate as a construction cost reduction measure and an environmental friendly Construction.

Performance of coconut shell concrete in heavy traffic pavements should be carried out by future researchers.

7 Standard concrete pavement produced at 1:2:4 mix ratios satisfied the minimum cementitious content of $215 \mathrm{~kg} / \mathrm{m}^{3}$ which is a function of durability as specified in PCA IS415.

\section{References}

AASHTO. Standard specifications for transportation materials and methods of sampling and testing, 33rd edition. American Association of State Highway and Transportation Officials, Washington, DC, USA. 2013; http://www.transportation.org.

AASHTO. Standard specifications for transportation materials and methods of sampling and testing, 35th edition. American Association of State Highway and Transportation Officials, Washington, DC, USA. 2015; http://www.transportation.org.

AASHTO M85-16, Standard specification for Portland cement. American Association of State Highway and Transportation Officials, Washington, DC, USA. 2016; http://www.transportation.org.

$\mathrm{ACl} 318 / 318 \mathrm{R}-08$, Building code requirements for structural concrete and commentary; $\mathrm{ACl}$ commit- tee 318. American concrete institute, Farmington Hills, MI. USA. 2009; http://www.concrete.org/318. htm.

Akshay, S.S., Kalyami R.N., Pooja P.K, and Shraddha P.G. "Coconut shell as partial replacement for coarse aggregate review", International journal of civil engineering research, 2014; Vol. 5(3): Pp 211214.

Amarnath, Y. and Ramachandrudu, C. "Properties of concrete with coconut shells as aggregate replacement", International journal of engineering inventions, 2012; Vol. 1 (6), Pp 21-31.

ASTM C136/C136M-14. Standard test method for sieve analysis of fine and coarse aggregates, ASTM International, West Conshohocken PA. 2014; http:// www.astm.org. 
ASTM D6913-04. Standard test method for particle size distribution (Gradation) of soils using sieve analysis. ASTM International, West Conshohocken PA. 2009; http:// www.astm.org.

ASTM D5874-02. "Standard test method for determination of the impact value (IV) of a Soil". ASTM International, West Conshohocken PA. 2007; http:// www.astm.org.

ASTM C131/C131M-14. Standard test method for resistance to degradation of small size coarse aggregate by abrasion and impact in the Los Angeles Machine, ASTM International, West Conshohocken PA. 2006; http:// www.astm.org.

ASTM C1157/C1157M-11, Standard specification for hydraulic cement. ASTM International, West Conshohocken PA. 2011; http:// www. astm.org.

ASTM C150/150M-16e1, Standard specification for Portland cement. ASTM International, West Conshohocken PA. 2016; http:// www.astm.org.

ASTM C143/C143M -15. Standard test method for slump of hydraulic cement concrete. ASTM International West Conshohocken, PA. 2015; http://www.astm.org.

ASTM C1611. Standard test method for slump flow of self consolidating concrete. ASTM International, West Conshohocken, PA.2015; http:// www.astm.org.

ASTM C94/C94M -15a. Standard specification for ready mixed concrete. ASTM International, West Conshohocken, PA. 2015; http://www. astm.org.

ASTM 127-15. Standard test method for relative density (specific density) and absorption of coarse aggregates. ASTM International, West Conshohocken, PA. 2015; http://www.astm.org.

ASTM C192/C192M -15. Standard practice for making and curing concrete test specimens in the laboratory. ASTM International, West Conshohocken, PA. 2015; http:// www.astm.org.

ASTM D448. Standard classification for sizes of aggregates for road and bridge construction. ASTM International, West Conshohocken PA. 2012; http://www.astm.org.

ASTM C33/C33M -13. Standard specifications for concrete aggregate. ASTM International, West Conshohocken PA. 2013; http://www. astm.org.

ASTM C29/C29M. Standard test method for bulk density (Unit Weight) and voids in aggregates. ASTM International, West Conshohocken PA. 2016; http://www.astm.org.
ASTM C495/C495M - 12. Standard test method for compressive strength of lightweight insulating concrete. ASTM International, West Conhohocken, PA. 2012; http://www.astm.org.

ASTM C330/C330M - 14. Standard specification for lightweight aggregates for structural concrete. ASTM International, West Conshohocken PA. 2014; http:// www.astm.org.

Gunasekaran, K., Kumar, P.S., and Lakshmipathy M. "Mechanical and bond properties of Coconut Shell Concrete", Construction and Building Materials, 2011; Vol. 25(1), Pp 92-98. https://doi.org/10.1016/j.conbuildmat.2010.06.053

Kakade, S.A and Dhawale, A.W. “Light weight aggregate concrete shell", International Journal of Technical Research and Applications, 2015; Vol. 3 (3), Pp 127 -129.

Naik, T.R. “Sustainability of concrete construction", Practice Periodical on Structural Design and Construction", 2008; Vol. 13(2), Pp 98 -103. https://doi.org/10.1061/ (ASCE)1084-0680(2008)13:2(98)

Olanipekun, E.A, Olusola, K.O and Ata, O. "A Comparative Study of coconut shell and palm kernel shell as coarse aggregates", Journal of Building and Environment, 2006; Vol. 41 (3), Pp 297 -301. https://doi.org/10.1016/j.buildenv.2005.01.029

Osei, D.Y. "Experimental assessment on coconut as aggregate in concrete", International Journal of Engineering Science Invention, 2013: Vol. 2 (5), Pp 07 -11.

Parag, S.K and Sandhya R.M. "Application of coconut shell as coarse aggregate in concrete: A technical review", International Journal of Engineering Research and Applications, 2014; Vol. 4 (3), Pp 498-501.

Shetty, M.S. "Concrete technology - theory and practice", 16th Edition, S. Chand and Company Limited, New Delhi, India; 2013.

Udoeyo F.F and Dashibil P.U. "Saw dust ash as concrete materials", Journal of Materials in Civil Engineering, 2002; Vol.14 (2), Pp. 173 -176. https://doi.org/10.1061/ (ASCE)0899-1561(2002)14:2(173)

WSDOT M46 - 01. 15. "Materials manual". Washington State Department of TransportationMaterials Laboratory, Washington D.C, USA, 2013; http://www.wsdot. wa.gov/publications/manual/m46-01.htm.

WSDOT M46 - 01. 24. "Materials manual". Washington State Department of Transportation Materials Laboratory, Washington D.C, USA, 2016; http://www.wsdot. wa.gov/publications/manual/m46-01.htm.

WSDOT M41 - 10. "Standard specifications". Washington State Department of Transportation Materials Laboratory, Washington D.C, USA, 2013; http://www. wsdot.wa.gov/publications/manual/full text/ m4110/ division9. 


\section{About the} authors

\section{ALBAN CHIDIEBERE OGBONNA}

\section{Lecturer/Researcher}

Department of civil engineering, college of engineering, Waziri Umaru Federal Polytechnic,

Birnin Kebbi, Kebbi State, Nigeria

\section{Main research area}

Pavement material engineering, Traffic engineering and Transportation engineering

\section{Address}

Department of civil engineering, college of engineering, Waziri Umaru Federal Polytechnic, Birnin Kebbi, P.M.B 1034, Birnin Kebbi GPO, Birnin Kebbi City, Kebbi State, Nigeria.

Tel. +2348039256430

E-mail: alban.ogbonna@yahoo.com

\section{ABUBAKAR MIKAILU}

Lecturer/Researcher

Department of civil engineering, college of engineering, Waziri Umaru Federal Polytechnic, Birnin Kebbi, Kebbi State, Nigeria

\section{Main research area}

Structural engineering, Foundation engineering and Concrete technology

\section{Address}

Department of civil engineering, college of engineering, Waziri Umaru Federal Polytechnic, Birnin Kebbi, P.M.B 1034, Birnin Kebbi GPO, Birnin Kebbi City, Kebbi State, Nigeria.

Tel. +2347031276736

E-mail: mikaabuba@gmail.com 